\title{
O USO DE ELEMENTOS E FIGURAS RETÓRICAS NO LAUDATE PUERI DE ANDRÉ DA SILVA GOMES
}

\section{THE USE OF ELEMENTS AND RHETORICAL FIGURES IN LAUDATE PUERI BY ANDRÉ DA SILVA GOMES}

\author{
Eliel Almeida Soares \\ Universidade de São Paulo \\ eliel.soares@usp.br
}

\section{Resumo}

artigo apresenta o uso de elementos e figuras retóricas no Laudate Pueri de André da Silva Gomes. Para tanto, haverá uma breve contextualização sobre o emprego retórico na música do final do século $\mathrm{XVI}$ até os primórdios do século XIX. Posteriormente, será exposto o interesse da musicologia dos últimos cinquenta anos em compreender a elaboração das estruturas retóricas. Consequentemente, mediante uma metodologia apoiada em análises retórico-musicais e em conformidade ao texto litúrgico, às funções harmônicas e à ordenação do discurso musical, se evidenciará que nessa obra esses recursos retóricos eram usados de maneira consciente pelo compositor.

Palavras-chave: retórica; análise musical; André da Silva Comes; música colonial brasileira.

\section{Abstract}

The article presents the use of elements and rhetorical figures in Laudate Pueri by André da Silva Comes. Thus, there will be a brief contextualization about the rhetorical use in music from the late 16th century until the early 19th century. Afterwards, the interest of musicology of the last fifty years in understanding the elaboration of rhetorical structures will be exposed. 
Consequently, through a methodology based on rhetorical-musical analyses and in conformity with the liturgical text, the harmonic functions and with the ordering of the musical discourse, it will be evident that in this work these rhetorical resources were consciously used by the composer.

Keywords: rhetoric; musical analysis; André da Silva Comes; Brazilian colonial music.

\section{Introdução}

Essencial para a constituição de um discurso, a retórica é o instrumento de persuasão objetivado em convencer o público através do emprego de artifícios linguísticos (ABBACNANO, 2007, p. 856). Em outras palavras, a finalidade precípua da arte da eloquência é a produção de um enunciado eficaz e consistente, o qual serve de embasamento e auxilio ao orador para adesão favorável dos ouvintes à tese por ele apresentada, evidenciando, dessa maneira, sua habilidade em empregar a linguagem para mover os afetos dos ouvintes (CUIMARÃES, 2004, p. 145). Para tanto, são necessários vários recursos, como metáforas, analogias, alegorias e figuras retóricas, os quais podem ser examinados desde a civilização greco-romana (SOARES; NOVAES; MACHADO NETO, 2012 b, p. 30 l). Diversos pensadores e teóricos como Aristóteles (394-322 a. C.), Cícero (106-43 a.C.), Quintiliano (c. 35-c. 96), Santo Agostinho (354-430), Santo Isidoro de Sevilha (570-636), entre outros, influenciaram o pensamento de vários tratadistas retóricomusicais, além de grande parte dos compositores do último quartel do século XVI e do princípio do século XIX (SOARES; NOVAES; MACHADO NETO, 2012a, p. 71). Desse modo, na música produzida nesse período eram colocados em prática os mesmos processos e dispositivos retóricos pelos autores, com o objetivo de clarificar o conteúdo dos enunciados musicais (SOARES; MACHADO NETO, 2015, p. 337).

Não obstante, esses preceitos são evidenciados na Arte explicada de contraponto, de André da Silva Comes (1752-1844)', que recomenda ao compositor estar bem informado, além de utilizar suas

\footnotetext{
I Régis Duprat enfatiza que o tratado pode ser localizado em cópia escrita em 1830 por Jerônimo Pinto Rodrigues, sem mencionar precisamente a data do exemplar original (DUPRAT et al., 1998, p. 9).
} 
formulações musicais com organização e diligência. Por fim, é ressaltado que o compositor deveria verificar, estudar e imitar os ótimos tratados dos notabilissimos mestres, além de embasar-se nos princípios próprios das faculdades retórica e poética (DUPRAT et al., 1998, p.179-180).

Em outro trecho de seu tratado, Silva Comes salienta a relevância da instrução retórica para que os compositores pudessem obter uma exposição segura e sólida:

Daqui pode concluir que o Compositor instruido, naõ so como Filosopho, a entidade differente de cada hum dos sobreditos empregos; podendo justamente distinguir - Contraponto Harmonia Docente, e a Composiçaõ Harmonia Utente, isto he, parte que dá preceitos; e parte, que os apprezenta em execuçaõ; mas tambem pode observar como Rhetorico a analogia da Faculdade Harmonica com a Faculdade Rhetorica; aqui se observa o Contraponto relativo a parte da Invençaõ e a Composição relativa a Disposiçaõ e a Elocuçaõ. Na Dissertaçaõ, que serve de principio a esta obra, fica [após?] demonstrando, quanto He precioza ao Compositor a Instruçaõ Literaria [sic]. (SILVA COMES, lição $n^{\circ}$ | f. 2. Nota do original apud DUPRAT et al., 1998, p. 17-18, grifos nossos).

Em suma, apoiando-se nessas afirmações, este artigo expõe o uso de elementos e figuras retóricas no Laudate Pueri de André da Silva Gomes, evidenciando que tais mecanismos eram aplicados com a finalidade de efetuar um discurso persuasivo e eloquente. A metodologia usada consiste em análises retórico-musicais, relacionadas ao texto litúrgico, à harmonia e disposição do discurso musical, as quais serão apresentadas ao longo do trabalho.

\section{O interesse da retórica musical para a musicologia dos últimos cinquenta anos}

Indispensável para a formulação das estruturas discursivas nas músicas produzidas durante o final do século XVI e princípio do século XIX, a retórica contribuiu para o esclarecimento de sua aplicação relacionada com a gramática e adequação na linguagem musical vigente da época. 
Tal processo foi constituido por intermédio de uma sistematização e teorização incrementada e aperfeiçoada por diversos autores, cuja premissa se fundamentava nos notabilíssimos mestres da retórica clássica, estabelecendo, assim, uma nomenclatura conhecida como Musica Poetica. Nessas obras, eram ressaltados os métodos e dispositivos necessários para que a música pudesse estar em consonância a um discurso eminentemente elaborado e organizado por elementos retóricos, objetivados em atrair, persuadir, impelir e mover os afetos de quem ouve (SOARES; MACHADO NETO, 2016, p. 651-652).

Nesse sentido, em seguimento à tradição de insignes tratadistas da música poética e retórica musical, como Gioseffo Zarlino (15171590), Gallus Dressler (1533-1589), Johannes Nucius (1556-1620), Joachim Burmeister (1564-1629), Johannes Luppius (1585-1612), Marin Mersenne (1588-1648), René Descartes (1596-1650), Athanasius Kircher (1601-1680), Wolfgang Caspar Printz (1641-1717), Johann George Ahle (1651-1706), Johann Mattheson (1681-1764), Johann Gottfried Walther (1684-1748), Johann Adolf Scheibe (1708-1776), Heinrich Christoph Koch (1749-1816) e Johann Nikolaus Forkel (1749-1818), para citar alguns, a musicologia dos últimos cinquenta anos iniciou várias pesquisas, tendo como meta observar a relação entre música e afeto, ou seja, análises musicais visando à clarificação dos mecanismos empregados na constituição do discurso musical (SOARES; MACHADO NETO, 20 16, p. 652).

Confirmando, dessa forma, que a retórica musical é um campo vasto, onde inúmeros trabalhos especializados são editados anualmente, devido aos abundantes tratados publicados entre 1535 e 1802 estabelecerem um elo com o corpus teórico do sistema retórico-musical, servindo de embasamento às atuais pesquisas acerca da poética musical barroca e clássica (LÓPEZ CANO, 2000, v. 1, p. 7).

\section{As fases retóricas}

Por intermédio de Aristóteles, a retórica foi reabilitada e integrada numa visão sistemática do mundo, onde ocupa seu lugar. Em outras palavras, Aristóteles transformou a retórica num sistema, o qual ulteriormente seus sucessores trataram de desenvolver, porém mantendo suas características principais (REBOUL, 2004, p. 43). 
Dessa forma, para melhor entendimento de como é organizado o discurso musical e o modo de o compositor trabalhar com cada elemento retórico, é relevante salientar que, com o passar dos tempos, estabeleceu-se como se conhece hoje a distribuição das cinco fases retóricas, expostas a seguir.

- Inventio - são descobertas pelo orador as ideias e os argumentos que sustentarão a sua tese, podendo abranger o ato de criação, das ideias musicais, entre outros.

- Dispositio - são distribuídos e ordenados ideias e argumentos localizados na Inventio.

- Elocutio - refere-se ao estilo. Nessa fase são estabelecidos os procedimentos de cada ideia para o desenvolvimento de cada parte e da sua ornamentação. É denominada Decoratio ou Elaboratio por outros autores.

- Memoria - são os mecanismos e processos empregados para memorizar o discurso e, por extensão, o sistema operacional de cada fase retórica.

- Pronuntatio - quando o discurso é proferido. É a última fase retórica, também conhecida como Actio ou ação (atuação). Corresponde à performance, ou seja, à interpretação diante do público.

Referente à Dispositio, alguns tratadistas, como Callus Dressler e posteriormente Joachim Burmeister, estabeleceram uma versão simplificada em três partes (Exordium, Medium e Finis). Todavia, em conformidade aos mestres da retórica e oratória clássica, Johann Mattheson ordena em seis partes, desta forma:

- Exordium - começo do discurso.

- Narratio - narração ou divulgação dos fatos.

- Propositio ou Divisio - esclarecimento da tese fundamental.

- Confutatio - refutação aos argumentos apresentados e contra as provas contrárias. Nessa parte se localizam as ideias contrastantes.

- Confirmatio - confirmação da tese inicial.

- Peroratio - conclusão (BUELOW, 200 I, p. 261-262). 


\section{Análise retórico-musical do Laudate Pueri de André da Silva Gomes ${ }^{2}$}

\section{Inventio}

Tendo seu texto extraído do livro dos Salmos (Ps. 112/113) ${ }^{3}$ o Laudate Pueri tem como epígrafe o Senhor, como o maior e mais digno objeto de louvor.

Laudate, pueri, Dominum; laudate nomen Domini.

Sit nomen Domini bebedictum, ex hoc nunc et usuque in sceculum.

A solis ortu usque ad occasum; laudate nomen Domini.

Excelsus super omnes gentes Dominus, Et super caelos gloria eius.

Quis sicut Dominus Deus noster, qui in altis habitat, et humilia respicit in coelo et in terra?

Suscitans a terra inopen, et de stercore erigen pauperem:

Ut collocet eum cum principibus, cum principibus populi sui. Qui habitare facit sterilem in domo, matrem filorum loetanterm. Gloria Patri et Filio et Spiritui Sancto. Sicut erat in principio et nunc et semper et in scecula sceculorum. Amen.

Louvai, ó servos, louvai o nome do Senhor.

Seja louvado o nome do Senhor, desde agora e para sempre. Desde o nascer do sol até o seu ocaso, seja louvado o nome do Senhor.

Excelso é o Senhor, sobre todas as gentes e a sua glória está acima dos céus.

Quem há como o Senhor nosso Deus, que está nas alturas, e abaixa os olhos sobre o cév e sobre a terra?

Levanta do pó o desvalido, e tira da imundície o pobre, Para o colocar com os príncipes, com os príncipes do seu povo. E a que era antes estéril, fá-la viver em sua casa, como mãe de seus filhos.

Glória ao Pai ao Filho e ao Espírito Santo. Assim como era o princípio, agora e sempre e por todos os séculos dos séculos. Amém.

2 Conforme o catálogo das obras de André da Silva Comes, organizado por Régis Duprat, esse salmo é datado de 1780 (DUPRAT, 1995, p. 185) e faz parte de um conjunto de três salmos que inclui igualmente o Salmo 121, Lœetatus Sum, e o Salmo 126, Nisi Dominus. Esse conjunto foi escrito para as Vésperas de Nossa Senhora.

3 Salmo 112 seria o número na bíblia católica; já na bíblia protestante o texto está escrito no número 113. 
Nos dez versículos desse Salmo, o salmista conclama os que devotam sua fé ao Senhor a louvá-lo, em todas as gerações e séculos. Esse ato se deve ao fato de Deus estar acima da criação, todavia Ele se faz presente ao seu povo. Somado a isso, para o povo hebreu esse Salmo é o primeiro dentre os vários que celebram as grandes festas anuais da Páscoa, das Semanas dos Tabernáculos, da Lua Nova e da Dedicação do Templo4 (ALMEIDA, 1999, p. 697).

Enfim, essa obra é constituída por 69 compassos, num andamento Andante na tonalidade Sol maior, ordenados em seis partes da Dispositio, trabalhadas pelo compositor com o propósito de despertar no ouvinte seus afetos.

\section{Dispositio}

\section{Exordium}

Salmo se inicia de maneira veemente e jubilosa; todas as vozes, por meio da dinâmica forte, entoam a expressão Laudate pueri Dominum (Louvai ó servos do Senhor). Nota-se, de igual forma, que André da Silva Comes utiliza a Epizeuxis, Palilogia e a Synaeresis, para reforçar ainda mais o afeto de júbilo e enaltecimento quando a palavra laudate é repetida por três vezes. Além disso, na mesma palavra o autor coloca em saliência as silabas da e te entre as funções da Tônica e Dominante com terminação na Cadência Autêntica Imperfeita. Por fim, no compasso 5, antes da entrada do solo, a pausa nas quatro vozes poderia ser considerada uma Aposiopesis, no entanto, para alguns tratadistas como

4 A festa da Páscoa ocorria no $14^{\circ}$ dia do primeiro mês (Abibe/março-abril). Ela lembra a libertação dos hebreus da escravidão do Egito. A festa das Semanas dos Tabernáculos acontecia entre os dias 15 e 22 do sétimo mês (Tisri/setembro-outubro), e nela era observada a provisão que Deus dava ao seu povo. A festa da Lua Nova ou das Trombetas ocorria no primeiro dia do sétimo mês (Tisri/setembro-outubro), e nela acontecia um descanso, um memorial, com sons de trombetas, quando nenhum trabalho poderia ser realizado; todavia, haveria de ser realizada uma oferta de sacrificio ao Senhor. Por fim, a festa da Dedicação do Templo, que tem oito dias de duração, celebra-se no nono mês (Quisleu/novembro-dezembro). Essa festa comemora a purificação e restauração do templo nos tempos de Judas Macabeu e a revolta judaica contra Antíoco Epifânio (164 a.C.) (ALMEIDA, 1999, passim).

5 As definições, citações e referências de todas as figuras retóricas serão apresentadas no tópico "Figuras observadas na obra", através de uma tabela. Outro ponto a ser salientado são as cores em forma retangular, que foram usadas somente para diferenciar as figuras retóricas localizadas. 
Thuringus, Nucius e Walther, seria uma figura retórica da Homoioptoton ou da Pausab, e para outros especialistas consiste numa figura musical de silêncio e não descreve um afeto (BARTEL, 1997, passim).

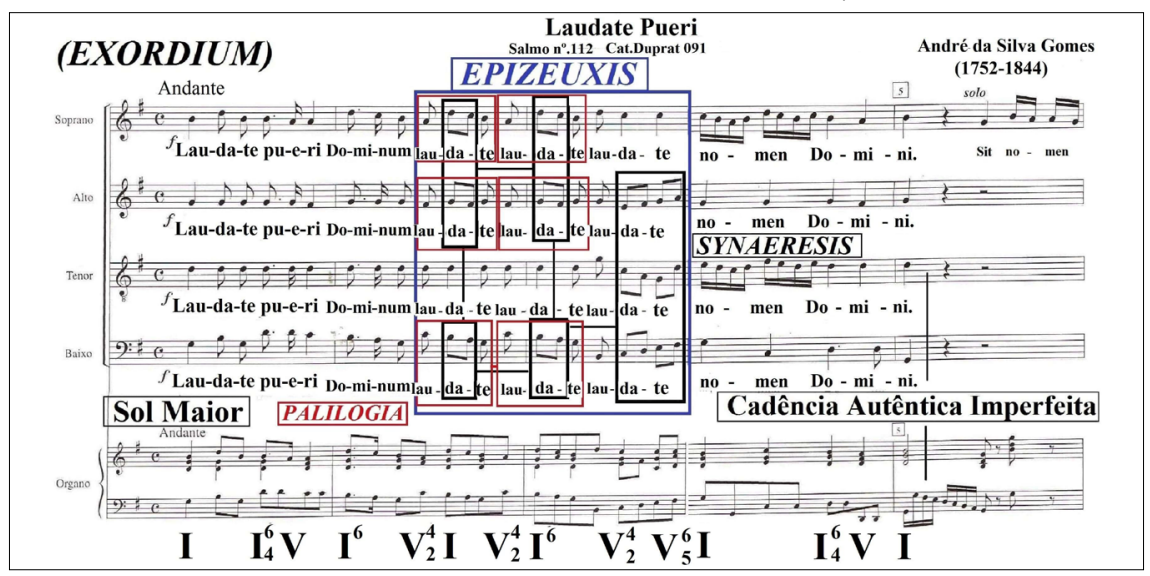

Figura 1: Epizeuxis, Palilogia e Synaeresis no Laudate Pueri de André da Silva Comes.

Compassos 2-3.

Fonte: Duprat (1999, p. 62).

\section{Narratio}

No solo da soprano é observável o uso da Synaeresis, onde a cada duas semicolcheias entoa-se uma silaba. Pode parecer trivial o emprego dessa figura, entretanto, o autor a inseriu para realçar o afeto de devoção representado pela Lœtitia?, através da frase Sit nomen Domini bebedictum, ex hoc nunc et usuque in sceculum (Seja louvado o nome do Senhor, desde agora e para sempre).

\section{Propositio}

Observa-se, entre os compassos 10 e 14, que Silva Comes continua a aplicar a Synaeresis em todas as vozes com o objetivo de destacar o afeto de encômio e louvor mediante as expressões A solis

6 Assim como a Aposiopesis, as duas figuras retóricas servem para propiciar um descanso a todas as vozes, na maior parte pode ser localizada em cadências no final de uma frase ou seção.

7 Benedictus de Spinoza (1632-1677) enfatiza que a Latitia pode causar afetos de prazer, amor, devoção, confiança, alegria, entre outros (JOACHIM, 1901, parte III, prop. LIX). 
ortu usque ad occasum; laudate nomen Domini (Desde o nascer do sol até o seu ocaso, seja louvado o nome do Senhor).

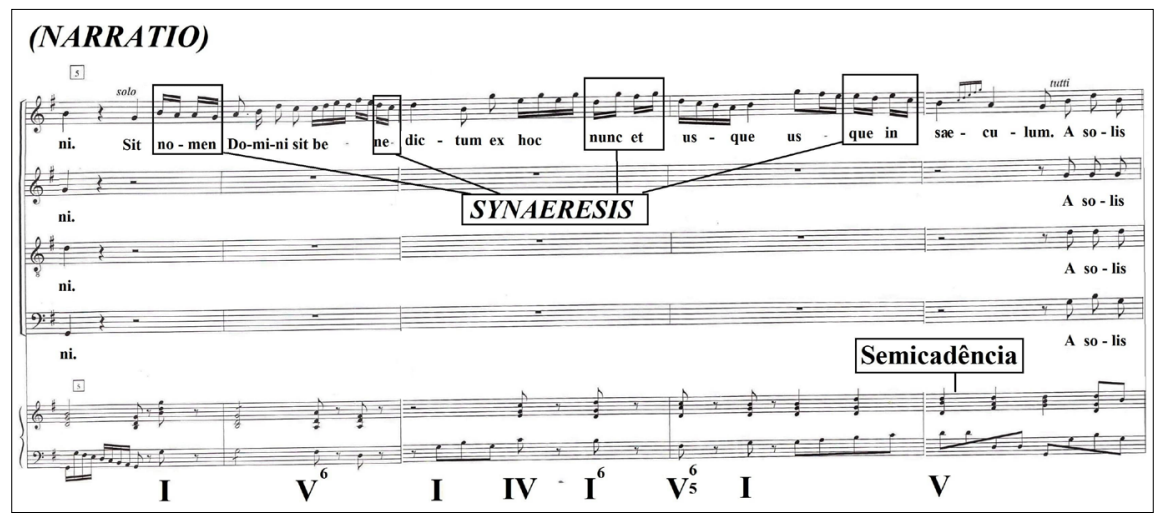

Figura 2: Synaeresis no Laudate Pueri de André da Silva Gomes. Compassos 5-8. Fonte: Duprat (1999, p. 62-63).

Igualmente, verifica-se que essa figura retórica, em consonância com as funções harmônicas, auxilia o deslocamento dos intervalos dissonantes de sétima situados na voz do contralto, no último tempo do compasso 10 (Sol sustenido - Lá), na Dominante da Dominante de Ré maior, assim como no quarto tempo do compasso 11 com as notas Lá e Sol sustenido, na sua Tônica paralela (relativa), na voz da soprano. Finalizando, outro aspecto a ser ressaltado são as duas cadências utilizadas nesse trecho: Semicadência com efeito suspensivo, no compasso 12, e a Autêntica Perfeita, no compasso 15.

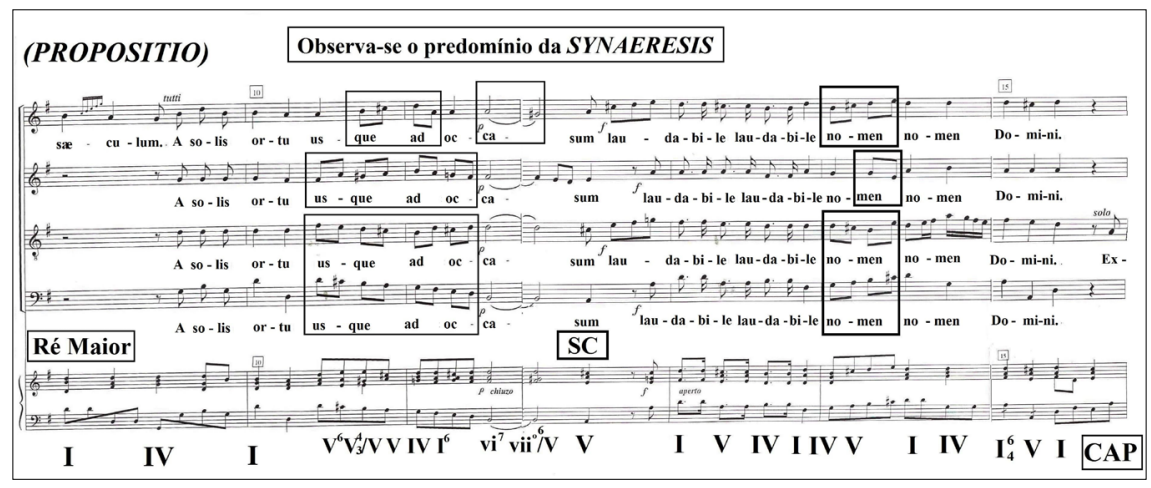

Figura 3: Synaeresis no Laudate Pueri de André da Silva Comes. Compassos 10-12, 14. Fonte: Duprat (1999, p. 63). 


\section{Confutatio}

Examina-se, na Figura 4, a predominância da Synaeresis no solo do tenor, onde o compositor novamente a utiliza com a finalidade de destacar a descrição feita pelo salmista da excelência, notabilidade e grandiosidade do Senhor, Excelsus super omnes gentes Dominus, Et super ccelos gloria eius (Excelso é o Senhor, sobre todas as gentes e a sua glória está acima dos céus).

Do mesmo modo, evidencia-se o uso da Synonymia, a qual repete as palavras gloria eius de maneira modificada, ou seja, realçando a ideia de que a glória de Deus está acima dos céus. Por fim, observamse as funções da Tônica, Dominante, Subdominante e Dominante da Dominante empregadas nesse trecho, além das cadências Autêntica Imperfeita, no compasso 19, e Autêntica Perfeita, no compasso 23.

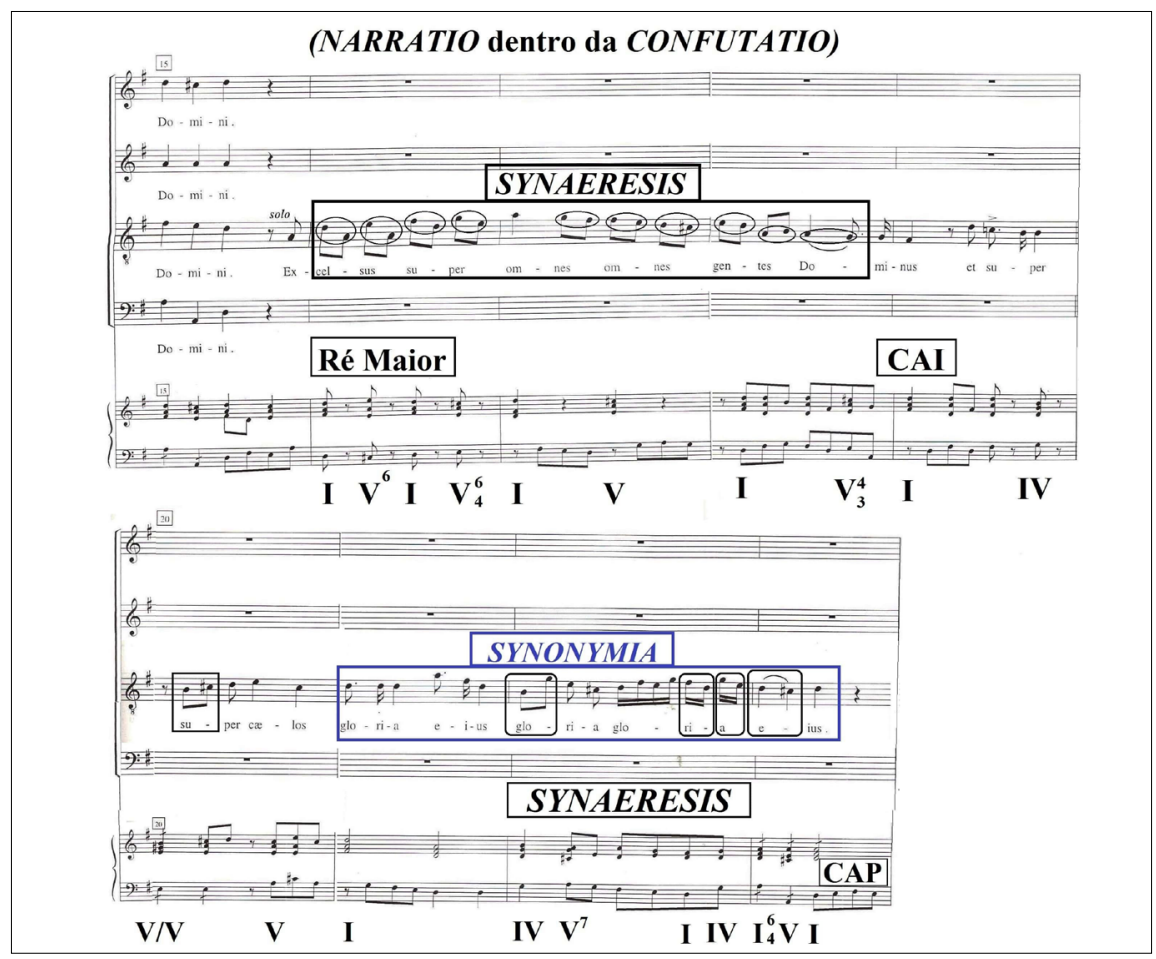

Figura 4: Synaeresis e Synonymia no Laudate Pueri de André da Silva Comes. Compassos 16-22. Fonte: Duprat (1999, p. 64-65). 
É tangível a predominância da Synaeresis, utilizada pelo autor para enfatizar não só as duas notas entoando uma silaba, mas principalmente a expressão Deus noster qui in altis habitat (Nosso Deus que está nas alturas). Também é visivel a aplicação da Epizeuxis enfatizando a expressão et humilia (se abaixa). Não obstante, é relevante destacar que, nesse contraponto textual de altura e baixeza, cév e terra, Silva Comes introduz uma mudança de tonalidade de Ré maior para Si menor, assim como da dinâmica forte no início da frase Quis sicut Dominus (Quem há como o Senhor), no compasso 24, para a dinâmica piano, nos compassos 28 e 29.

No excerto da Figura 6, nota-se, além da Epizeuxis e da Synaeresis, empregadas pelo compositor para ressaltar por meio de repetição as expressões humilia e Suscitans a terra, além do deslocamento e entoação de uma sílaba por duas notas, a figura retórica da Interrogatio, a qual coloca em evidência a frase Quis sicut Dominus Deus noster, qui in altis habitat, et humilia respicit in coelo et in terra? (Quem há como o Senhor nosso Deus, que está nas alturas, e abaixa os olhos sobre o cév e sobre a terra?), com terminação numa cadência na Dominante. 


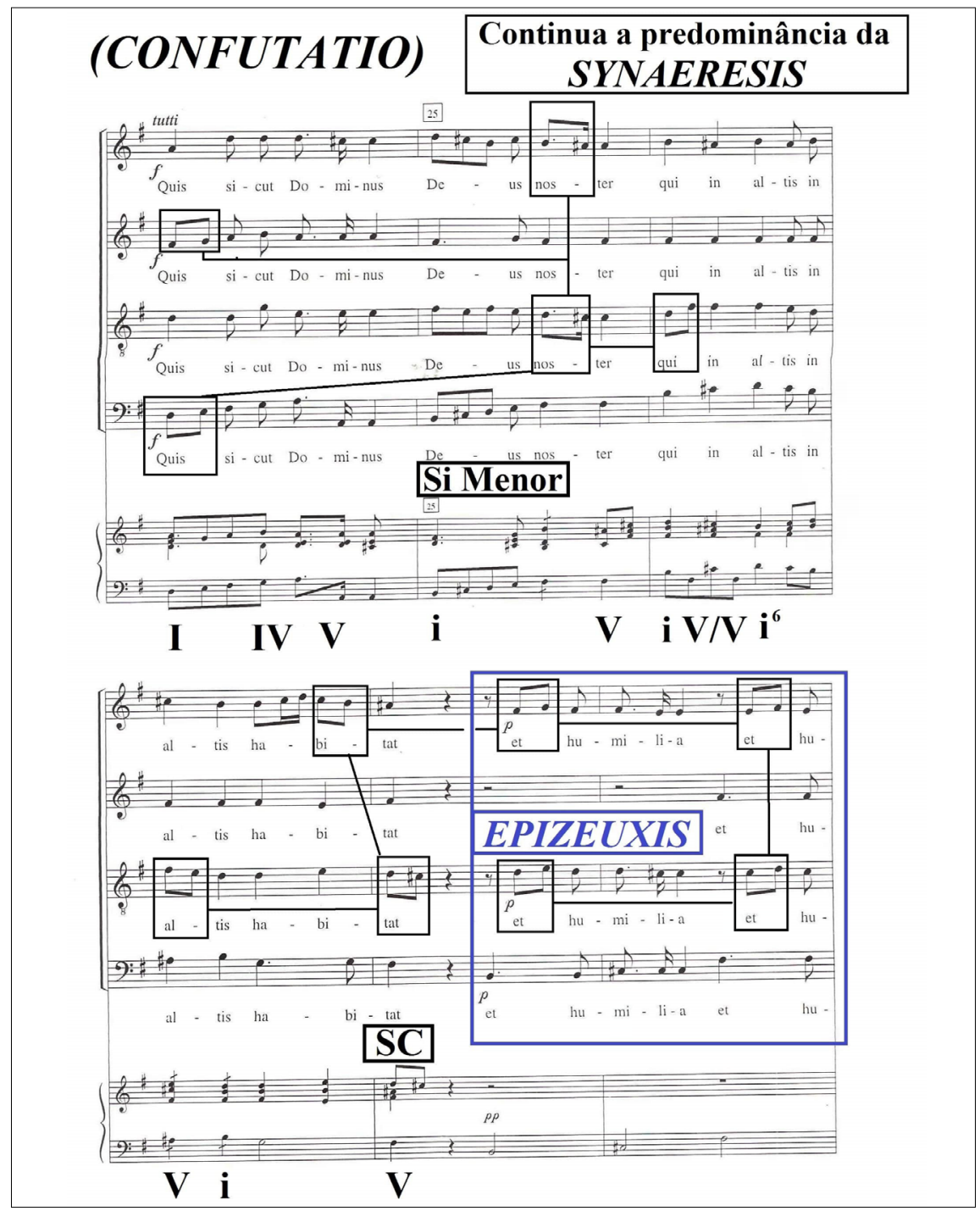

Figura 5: Synaeresis e Epizeuxis no Laudate Pueri de André da Silva Comes. Compassos 24-29. Fonte: Duprat (1999, p. 66). 


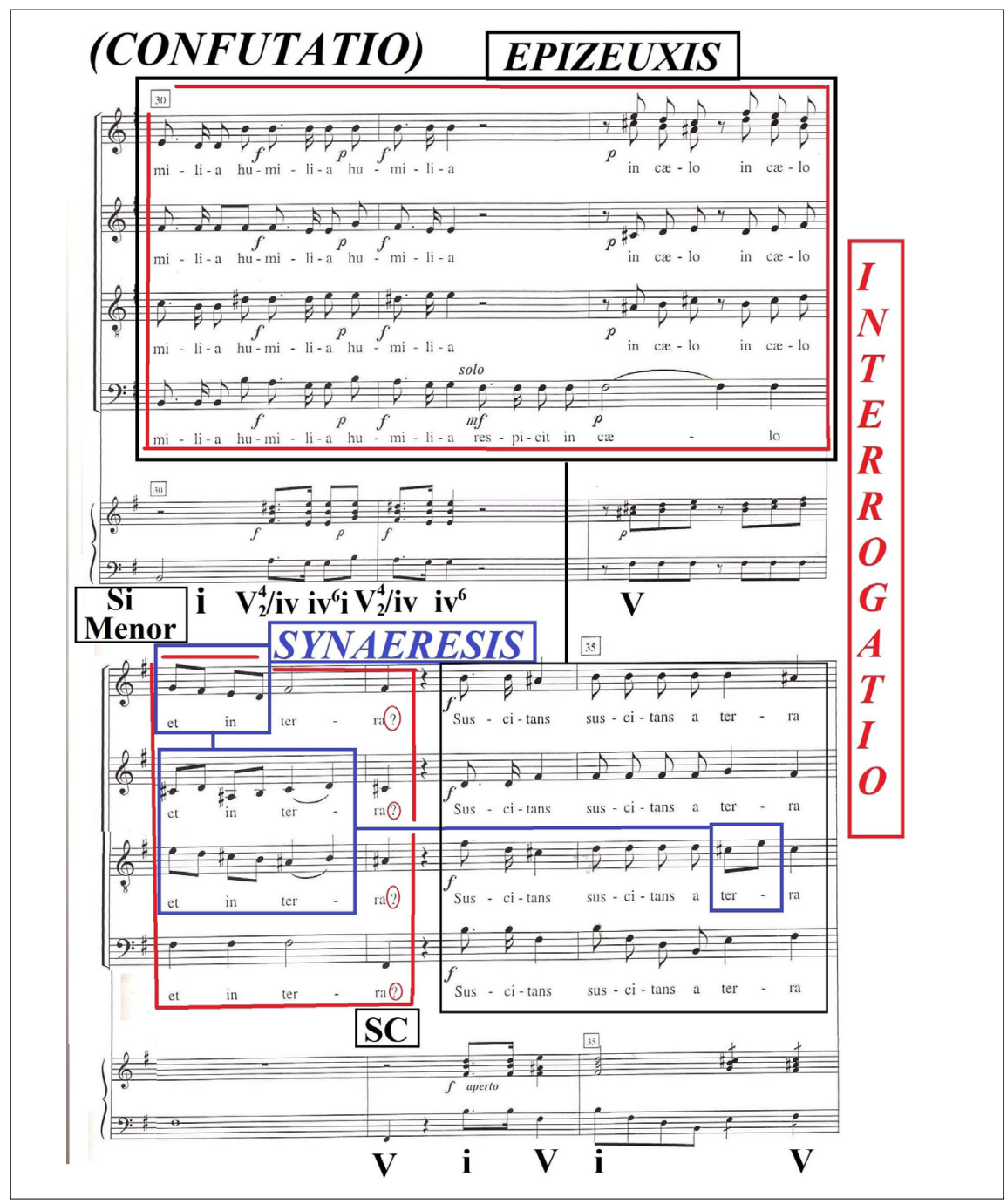

Figura 6: Epizeuxis, Interrogatio e Synaeresis no Laudate Pueri de André da Silva Gomes. Compassos 30-35.

Fonte: Duprat (1999, p. 67).

Averígua-se, nesse trecho, o uso da Epizeuxis e da Synaeresis nas vozes do contralto, no compasso 36, e nas vozes da soprano, do tenor e do baixo, no compasso 40, além do desenvolvimento harmônico realizado pelas funções da Tônica, Dominante sem fundamental, 
Subdominante, Dominante da Tônica paralela (relativa), Tônica paralela (relativa) e Dominante, finalizando na fundamental do acorde de Si menor, numa cadência Autêntica Perfeita.
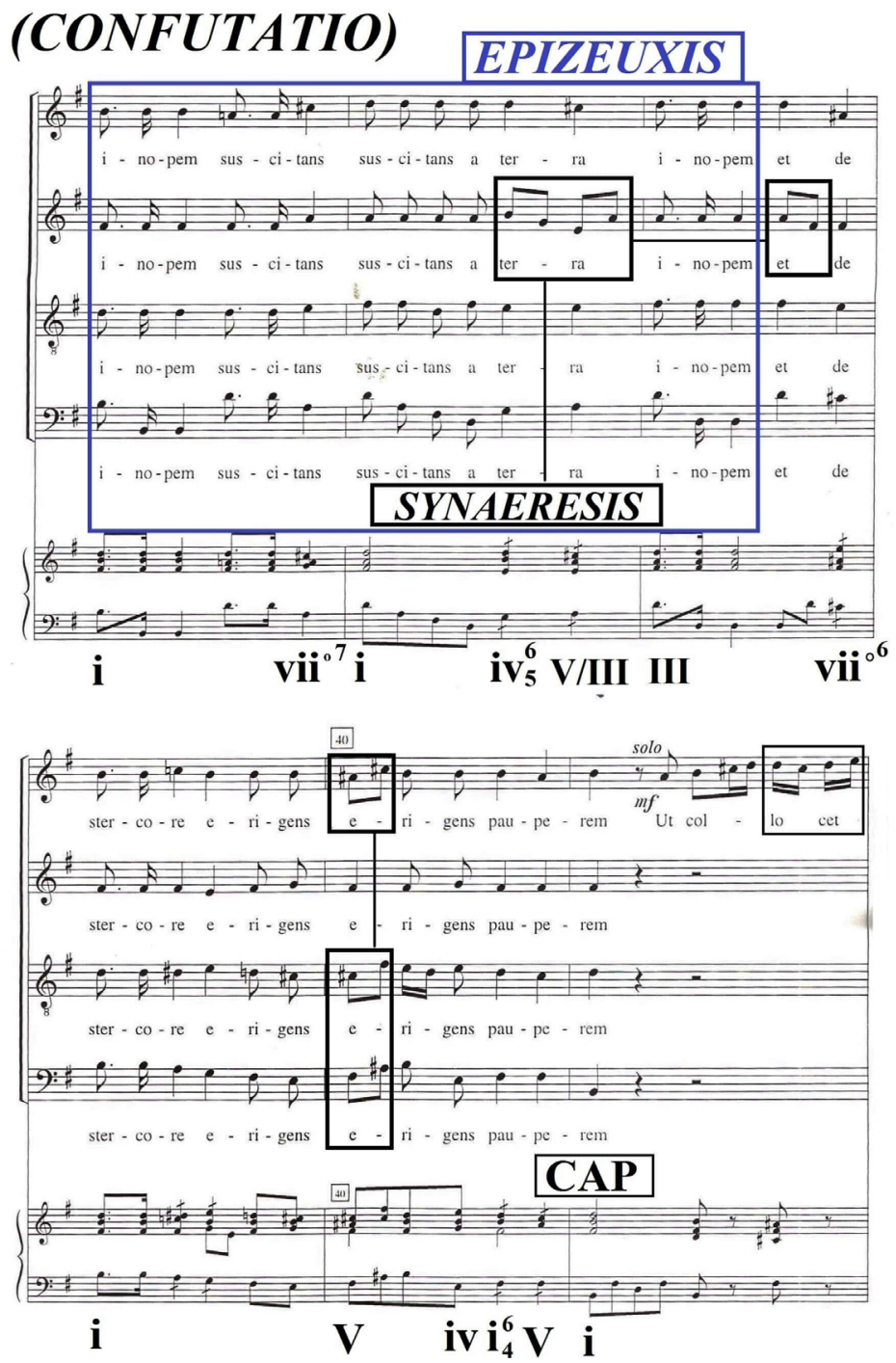

Figura 7: Epizeuxis e Synaeresis no Laudate Pueri de André da Silva Gomes.

Compassos 36-38, 40.

Fonte: Duprat (1999, p. 68). 
No solo da soprano constata-se a aplicação das mesmas figuras retóricas, ressaltando o afeto de engrandecimento, através da expressão cum principibus populi sui (como príncipes seu povo).

\section{(NARRATIO dentro da CONFUTATIO)}

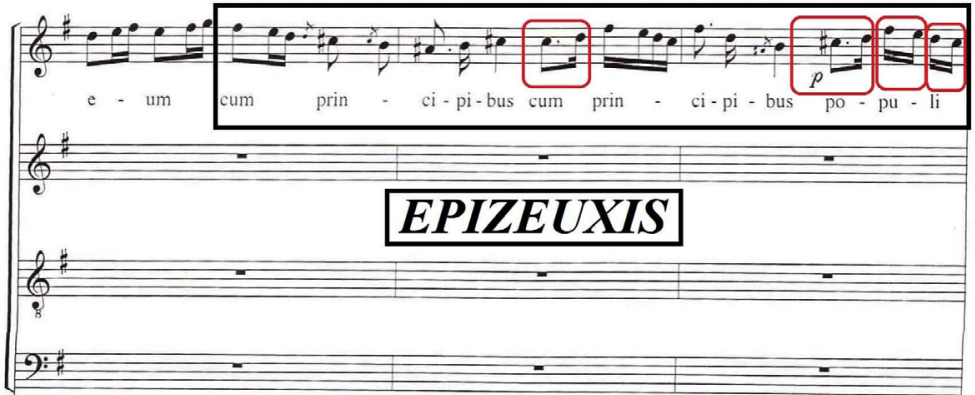

Si Menor
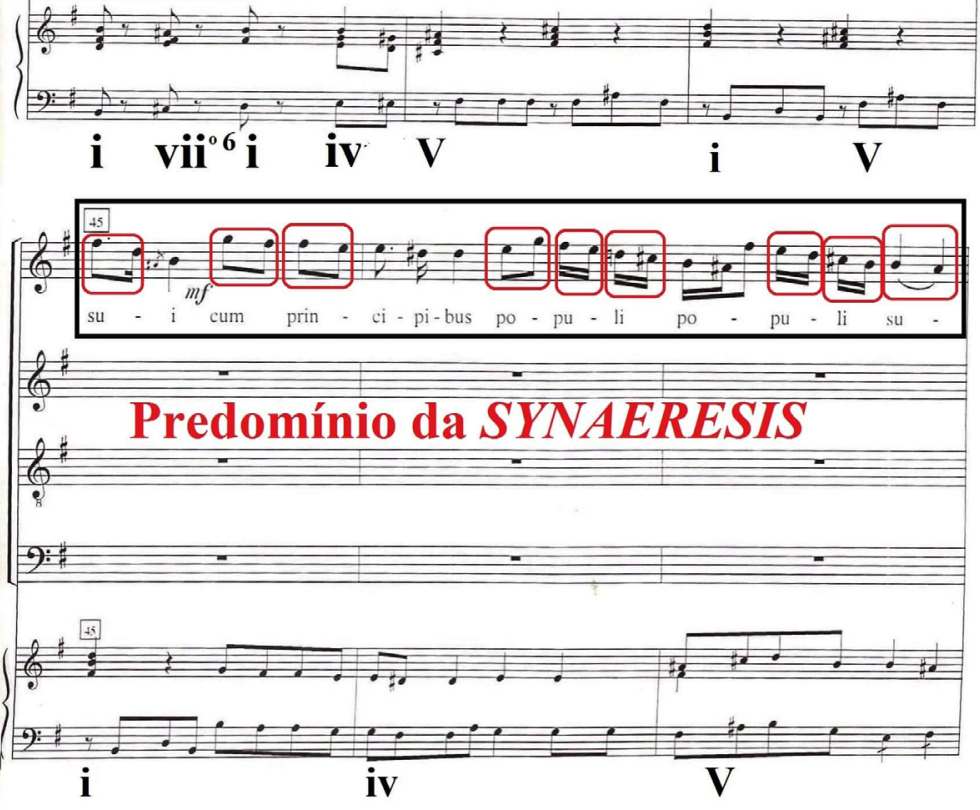

Figura 8: Epizeuxis e Synaeresis no Laudate Pueri de André da Silva Gomes.

Compassos 42-47.

Fonte: Duprat (1999, p. 69). 
Nos compassos 48 a 56 do Laudade Pueri, é exposta a parte final da Confirmatio, onde a expressão Qui habitare facti strilem in domo/ matrem filorum loetantem (E a que era antes estéril, fá-la viver em casa, como alegre mãe de seus filhos) é enfatizada pelas notas e vozes. Por sua vez, examina-se o emprego da Abruptio juntamente com a Pausa, ressaltando, através desse silêncio imposto abrupta e inesperadamente, além da separação entre pausas das palavras facti strilem, os afetos de prazer, alegria e confiança expressados pelo salmista.

De igual maneira, destaca-se o uso da Synaeresis, nas vozes da soprano entoando as notas Dó sustenido e Ré, Ré e Mi, o tenor entoando as notas Ré e Mi, Mi e Fá sustenido e, por fim, o baixo entoando as notas Mi e Ré, Ré e Lá, Fá, repetindo em forma sequencial por três vezes.

Enfim, esse estado de espírito pode ser notado através da passagem homofônica entre Tônica, Dominante da Dominante e Dominante, na mudança da tonalidade Si menor para Ré maior, trabalhado por Silva Comes com o propósito de atrair a atenção do ouvinte.

\section{Confirmatio}

Nota-se, a partir do compasso 54, a utilização da Synaeresis, a qual dá ênfase à expressão Gloria Patri et Filio et Spiritui Sancto (Clória ao Pai, ao Filho e ao Espírito Santo). Destarte, a Aposiopesis é aplicada para oferecer um descanso para todas as vozes, além de ressaltar a cadência Autêntica Perfeita e antecipar a entrada do duo, da soprano e contralto, na tonalidade inicial da obra, isto é, em Sol maior. 


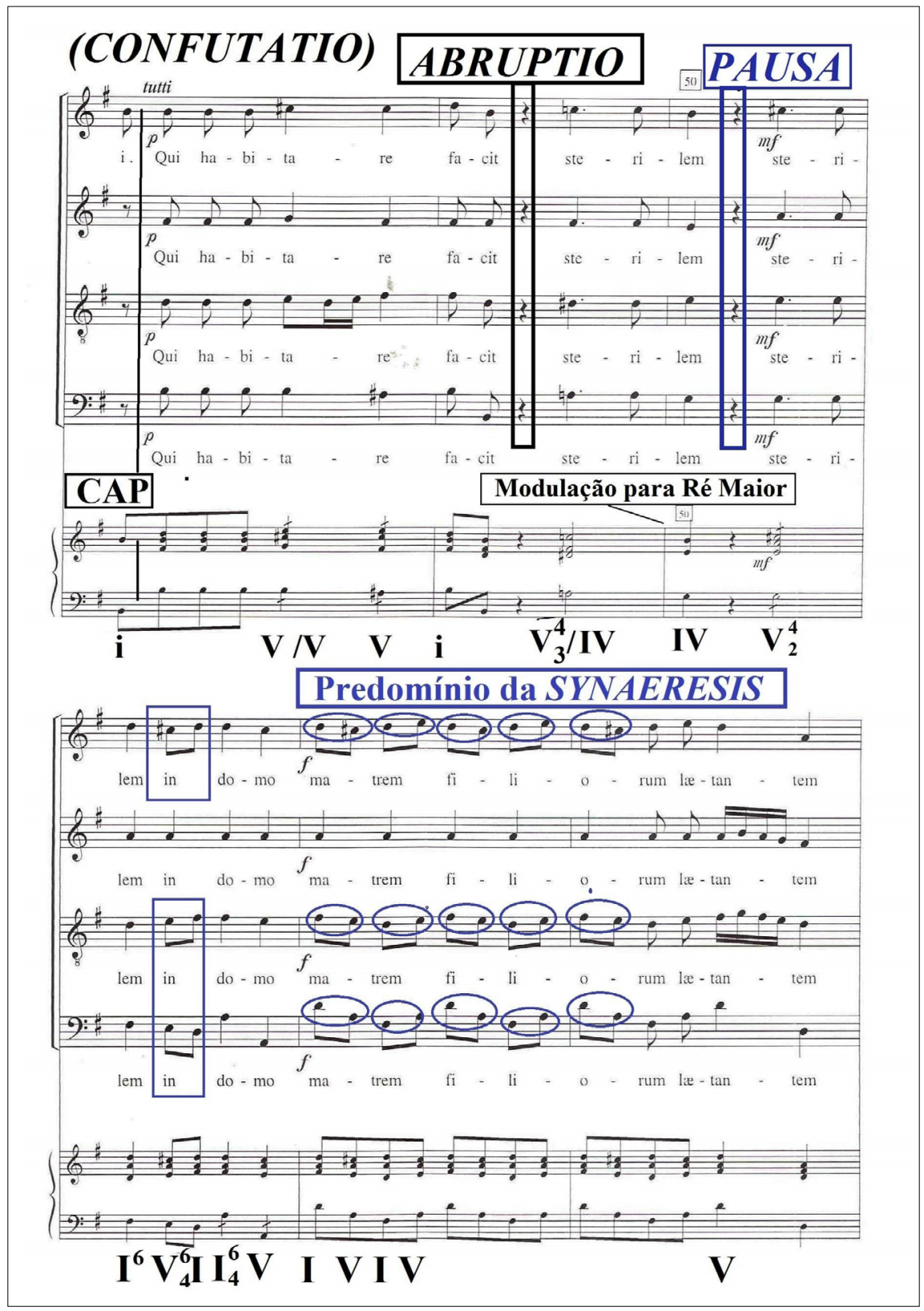

Figura 9: Abruptio, Pausa e Synaeresis no Laudate Pueri de André da Silva Gomes. Compassos 48-56. Fonte: Duprat (1999, p. 70). 
(CONFUTATIO)

(CONFIRMATIO)

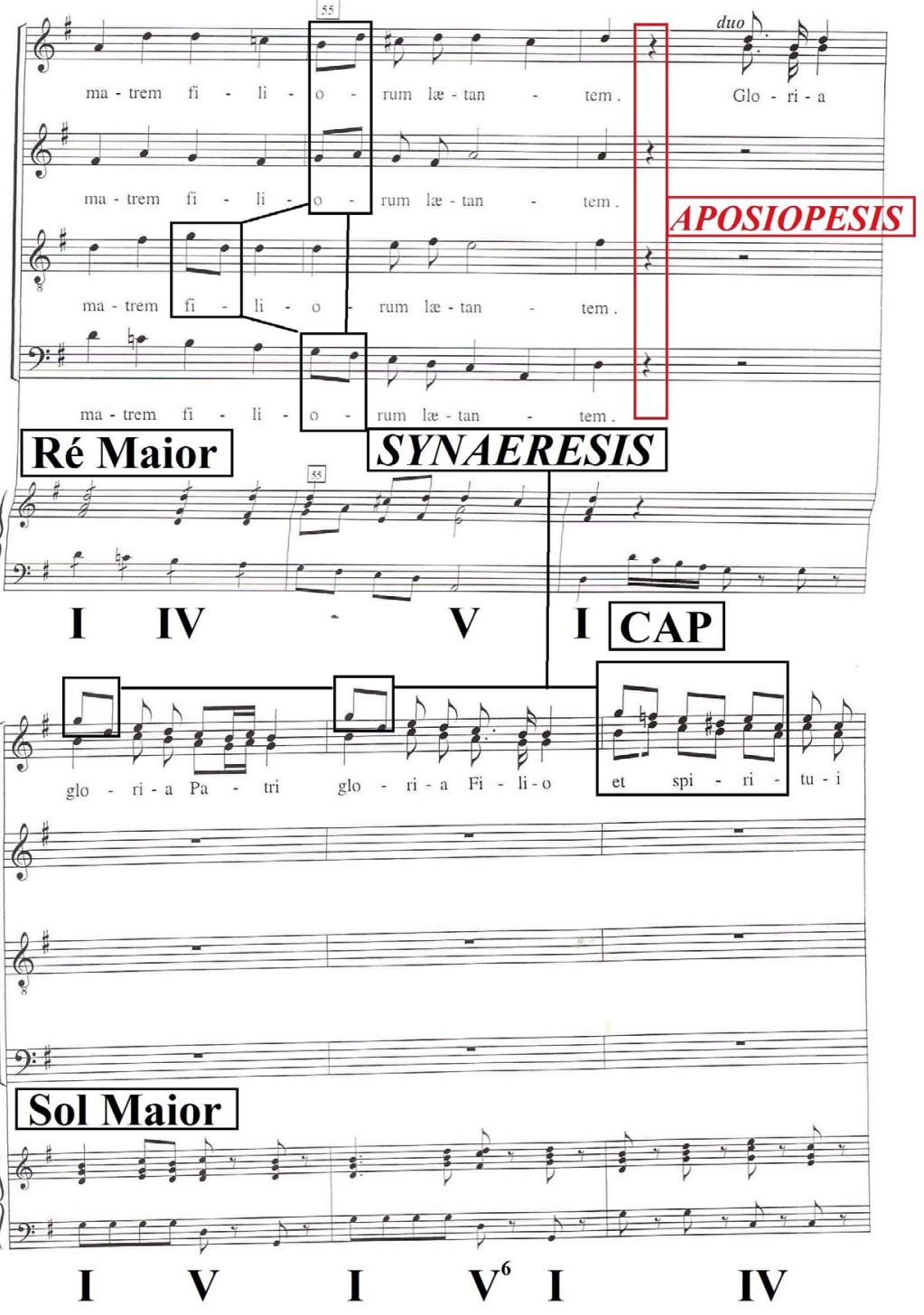

Figura 10: Synaeresis e Aposiopesis no Laudate Pueri de André da Silva Comes. Compassos 54-59.

Fonte: Duprat (1999, p. 71 ). 
É observável que o autor trabalha com os mesmos elementos retóricos utilizados em seções anteriores, ou seja, a Synaeresis e Epizeuxis.

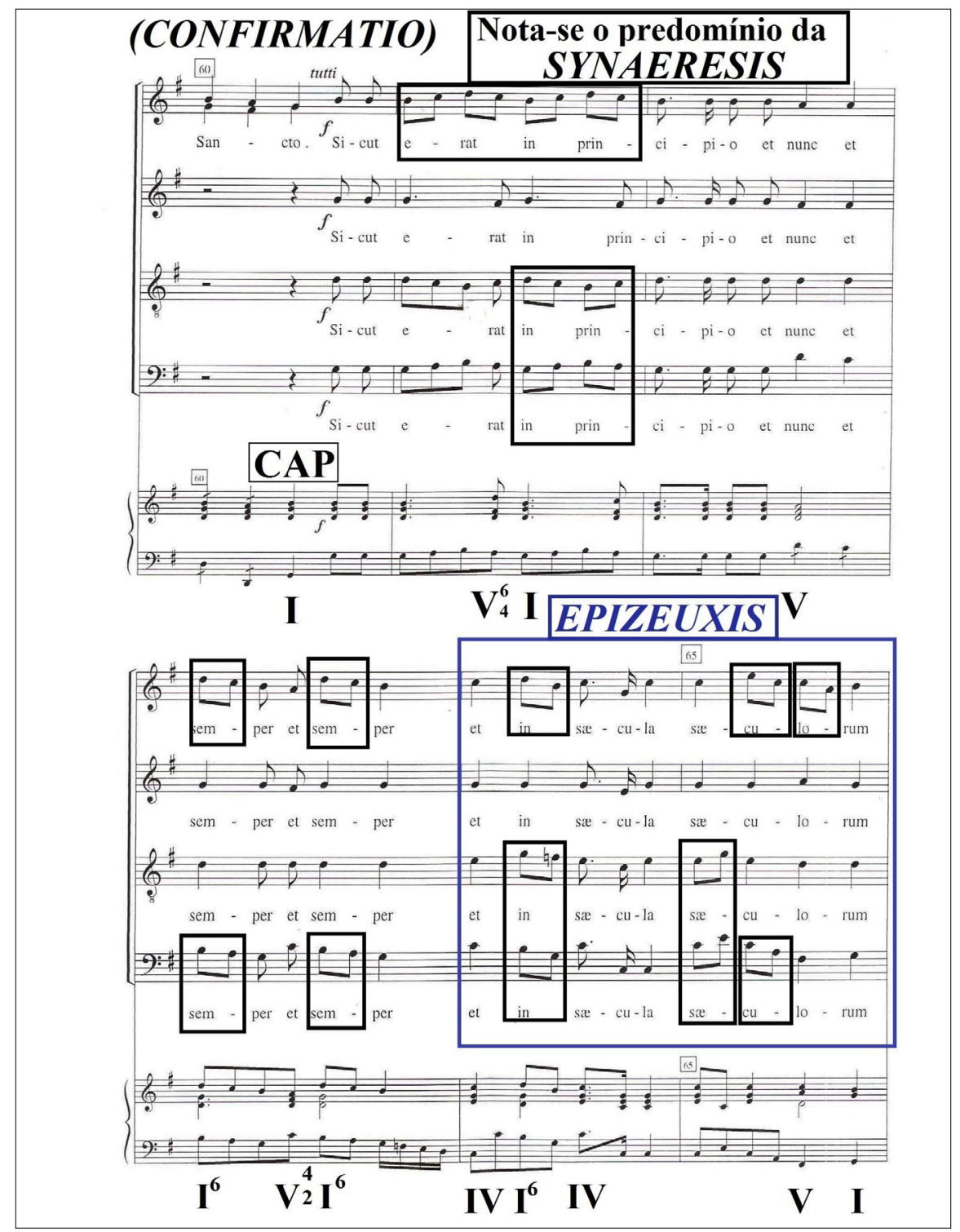

Figura 1 1: Synaeresis e Epizeuxis no Laudate Pueri de André da Silva Gomes. Compassos 61,63-65.

Fonte: Duprat (1999, p. 72). 


\section{Peroratio}

A conclusão do discurso se dá mediante as figuras supracitadas da Epizeuxis e Synaeresis. Por meio delas, Silva Gomes reproduz o afeto de certeza, confiança, convicção da conclamação do salmista dirigida ao povo hebreu, de enaltecimento à magnificência do Senhor, além de seus atributos e das bênçãos que Ele poderia propiciar, destacando a frase amem (assim seja), numa cadência Autêntica Imperfeita.

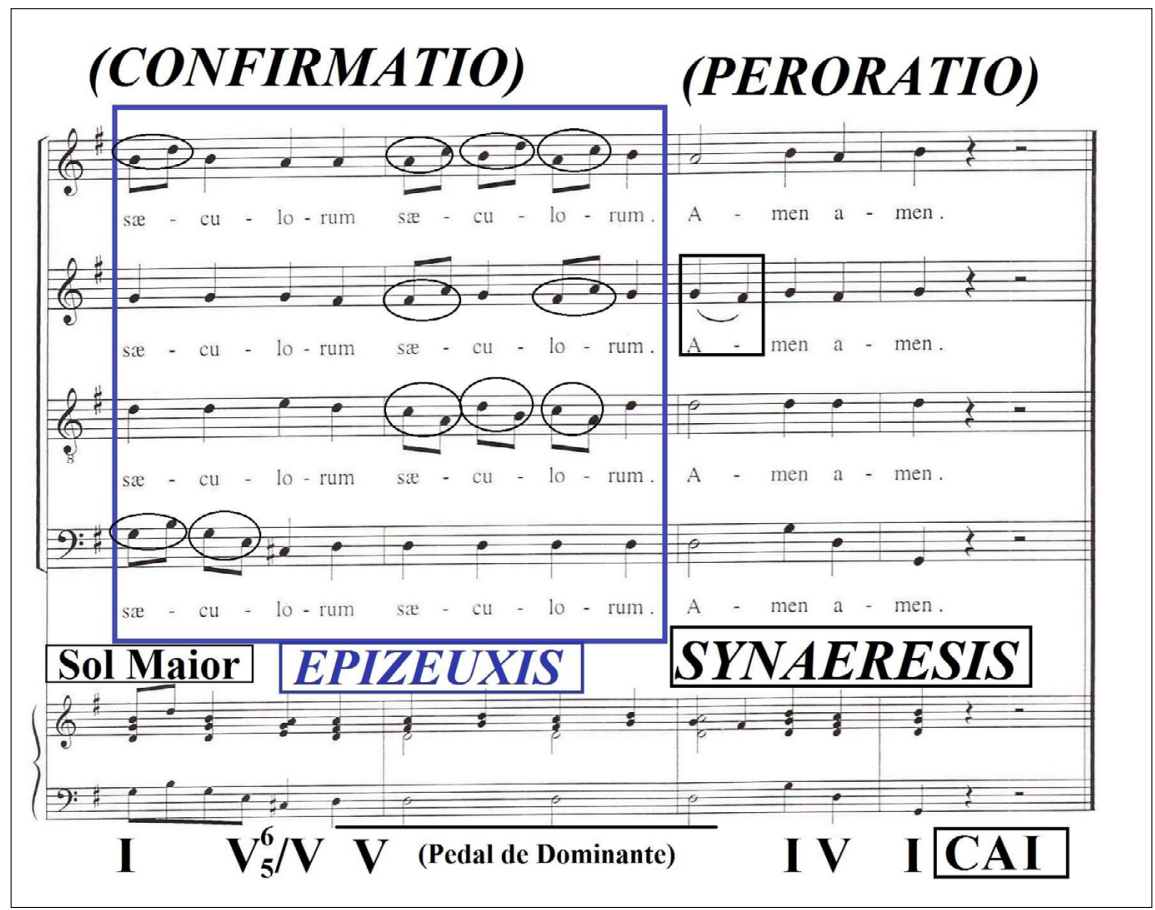

Figura 12: Epizeuxis e Synaeresis no Laudate Pueri de André da Silva Comes.

Compassos 66-69.

Fonte: Duprat (1999, p. 73). 


\section{Figuras observadas na obra (Elocutio/Decoratio)}

Tabela I: Figuras retóricas localizadas no Laudate Pueri de André da Silva Comes

\begin{tabular}{|c|c|c|}
\hline $\begin{array}{l}\text { FIGURAS E } \\
\text { CITAÇÕES }\end{array}$ & TIPO & DESCRIÇÃO \\
\hline $\begin{array}{l}\text { Abruptio } \\
\text { (BARTEL, 1997, } \\
\text { p. 168-170). }\end{array}$ & $\begin{array}{l}\text { Interrupção e } \\
\text { silêncio }\end{array}$ & $\begin{array}{l}\text { Uma quebra súbita } \\
\text { e inesperada } \\
\text { na composição } \\
\text { musical. }\end{array}$ \\
\hline
\end{tabular}

\begin{tabular}{|c|c|c|c|}
\hline $\begin{array}{l}\text { Aposiopesis } \\
\text { (BARTEL, } \\
\text { 1997, } \\
\text { p. 202-206). }\end{array}$ & $\begin{array}{l}\text { Interrupção e } \\
\text { silêncio }\end{array}$ & $\begin{array}{l}\text { Um descanso em } \\
\text { uma ou todas } \\
\text { as vozes de uma } \\
\text { composição: } \\
\text { pausa geral. }\end{array}$ & $\begin{array}{l}\text { Johann Gottfried Walther: } \\
\text { "A Aposiopesis se refere } \\
\text { a uma pausa generalis } \\
\text { ou um completo silêncio } \\
\text { em todas as vozes e nas } \\
\text { partes da composição } \\
\text { simultaneamente". }\end{array}$ \\
\hline $\begin{array}{l}\text { Epizeuxis } \\
\text { (BARTEL, } \\
\text { 1997, } \\
\text { p. 263-265). }\end{array}$ & $\begin{array}{l}\text { Repetição } \\
\text { melódica }\end{array}$ & $\begin{array}{l}\text { Uma repetição } \\
\text { imediata e } \\
\text { enfática de uma } \\
\text { palavra, nota, } \\
\text { motivo ou frase. }\end{array}$ & $\begin{array}{l}\text { Johann Gottfried Walther: } \\
\text { "A Epizeuxis é uma figura } \\
\text { de retórica pela qual } \\
\text { uma ou mais palavras } \\
\text { são imediatamente e } \\
\text { enfaticamente repetidas". }\end{array}$ \\
\hline $\begin{array}{l}\text { Interrogatio } \\
\text { (BARTEL, 1997, } \\
\text { p. } 312-3 \text { 16). } \\
\text { (BUELOW, } \\
2001 \text {, p. 267). }\end{array}$ & $\begin{array}{l}\text { Representação } \\
\text { e descrição }\end{array}$ & $\begin{array}{l}\text { Uma interrogação } \\
\text { musical, gerada } \\
\text { por: a) pausa, b) } \\
\text { cadência (Frígia, } \\
\text { Imperfeita ou } \\
\text { Semicadência), } \\
\text { c) movimento } \\
\text { ascendente na } \\
\text { nota final da frase } \\
\text { musical. }\end{array}$ & $\begin{array}{l}\text { Sethus Calvisius: "A } \\
\text { Interrogatio pode ser utilizada } \\
\text { numa cadência Imperfeita } \\
\text { terminando na Dominante } \\
\text { para expressar uma pergunta". } \\
\text { Christoph Bernhard: } \\
\text { "A Interrogatio ocorre } \\
\text { quando perguntas são } \\
\text { constantemente expressas } \\
\text { finalizando a frase uma } \\
\text { segunda acima da nota e } \\
\text { silaba anteriores". } \\
\text { Johann Scheibe: } \\
\text { "Interrogatio é uma pergunta } \\
\text { musical, no fim da melódica } \\
\text { ou de uma passagem } \\
\text { harmónica tendo no final } \\
\text { uma segunda ou algum } \\
\text { outro intervalo superior } \\
\text { a nota ou das notas } \\
\text { anteriores; Também pode } \\
\text { ocorrer na Cadência Frígia". }\end{array}$ \\
\hline
\end{tabular}




\begin{tabular}{|c|c|c|c|}
\hline $\begin{array}{l}\text { FIGURAS E } \\
\text { CITAÇÕES }\end{array}$ & TIPO & DESCRIÇÃO & TRATADISTA \\
\hline $\begin{array}{l}\text { Pausa } \\
\text { (BARTEL, 1997, } \\
\text { p. 362-365). }\end{array}$ & $\begin{array}{l}\text { Interrupção e } \\
\text { silêncio }\end{array}$ & $\begin{array}{l}\text { Uma pausa ou } \\
\text { descanso na } \\
\text { composição } \\
\text { musical. }\end{array}$ & $\begin{array}{l}\text { Johann Gottfried Walther: } \\
\text { "Pausa refere-se a um } \\
\text { período de repouso ou } \\
\text { o silêncio na música, } \\
\text { que é indicado por um } \\
\text { determinado sinal". }\end{array}$ \\
\hline $\begin{array}{l}\text { Palilogia } \\
\text { (BARTEL, 1997, } \\
\text { P. 342-344). } \\
\text { (BUELOW, } \\
\text { 200 I, p. 264). }\end{array}$ & $\begin{array}{l}\text { Repetição } \\
\text { melódica }\end{array}$ & $\begin{array}{l}\text { Repetição de um } \\
\text { tema no mesmo } \\
\text { nivel de altura, } \\
\text { também pode } \\
\text { ocorrer em alturas } \\
\text { diferentes na } \\
\text { mesma ou em várias } \\
\text { vozes. }\end{array}$ & $\begin{array}{l}\text { Joachim Burmeister: "A } \\
\text { Palilogia é uma repetição de } \\
\text { uma inteiração ou apenas } \\
\text { o começo da estrutura } \\
\text { dos meios e temas sobre a } \\
\text { mesma altura com a mesma } \\
\text { voz, ocorrendo com ou sem } \\
\text { intermédio de pausas em } \\
\text { todos os eventos em uma voz". } \\
\text { Johann Gottfried Walther: } \\
\text { "A Palilogia refere-se a uma } \\
\text { repetição por demais frequente } \\
\text { das mesmas palavras". }\end{array}$ \\
\hline $\begin{array}{l}\text { Synaeresis } \\
\text { (BARTEL, 1997, } \\
\text { p. 394-396). }\end{array}$ & $\begin{array}{l}\text { Dissonância e } \\
\text { deslocamento }\end{array}$ & $\begin{array}{l}\text { (1) Uma suspensão } \\
\text { ou síncope, (2) } \\
\text { a colocação de } \\
\text { duas silabas por } \\
\text { nota ou duas } \\
\text { notas por sílaba. }\end{array}$ & $\begin{array}{l}\text { Mauritius Johann Vogt "A } \\
\text { Synaeresis ocorre quando } \\
\text { duas notas são colocadas } \\
\text { em uma sílaba ou duas } \\
\text { sílabas são colocadas em } \\
\text { uma nota". }\end{array}$ \\
\hline $\begin{array}{l}\text { Synonymia } \\
\text { (BARTEL, 1997, } \\
\text { p. 405-407). } \\
\text { (BUELOW, } \\
\text { 2001, p. 264). }\end{array}$ & $\begin{array}{l}\text { Repetição } \\
\text { melódica }\end{array}$ & $\begin{array}{l}\text { É a repetição } \\
\text { alterada ou } \\
\text { modificada de } \\
\text { uma ideia musical. } \\
\text { A repetição de } \\
\text { uma ideia melódica } \\
\text { em notas diferentes } \\
\text { na mesma parte. }\end{array}$ & $\begin{array}{l}\text { Johann Gottfried Walther: } \\
\text { "Um compositor também } \\
\text { pode empregar muito bem } \\
\text { diferentes figuras retóricas } \\
\text { na elaboração de um } \\
\text { texto. Por exemplo, além } \\
\text { da Epizeuxis, que é a mais } \\
\text { comum e enfática, pode } \\
\text { usar, Anaphora, Synonymia, } \\
\text { Epistrophe, Epanalepsis e } \\
\text { assim por diante". }\end{array}$ \\
\hline
\end{tabular}




\section{Estrutura analítica da obra: Retórica e Harmônica}

\begin{tabular}{|c|c|c|c|c|}
\hline $\begin{array}{l}\text { RETÓRICA } \\
\text { DISPOSITIO }\end{array}$ & $\begin{array}{l}\text { FIGURA } \\
\text { ELOCUTIO }\end{array}$ & COMP. & TONALIDADE & FUNÇÃO \\
\hline \multirow{4}{*}{ Exordium } & Epizeuxis & $2-3$ & Sol maior & I \\
\hline & Palilogia & $2-3$ & Sol maior & I \\
\hline & Synaeresis & $2-3$ & Sol maior & I \\
\hline & Aposiopesis & 5 & Sol maior & I \\
\hline Narratio & Synaeresis & $5-8$ & Sol maior & I \\
\hline Propositio & Synaeresis & $\begin{array}{c}10-12 \\
14\end{array}$ & $\begin{array}{l}\text { Ré maior } \\
\text { Ré maior }\end{array}$ & $\begin{array}{l}V \\
V\end{array}$ \\
\hline \multirow{7}{*}{ Confutatio } & Synaeresis & $\begin{array}{l}16-18 \\
22-23 \\
24-28 \\
33-34 \\
37-38 \\
40-41 \\
43-47 \\
51-55 \\
\end{array}$ & $\begin{array}{l}\text { Ré maior } \\
\text { Ré maior } \\
\text { Ré maior, Si menor } \\
\text { Si menor } \\
\text { Si menor } \\
\text { Si menor } \\
\text { Si menor } \\
\text { Ré maior } \\
\end{array}$ & $\begin{array}{l}V \\
V \\
V_{\text {, iii }} \\
\text { iii } \\
\text { iii } \\
\text { iii } \\
\text { iii } \\
V \\
\end{array}$ \\
\hline & Synonymia & $21-23$ & Ré maior & V \\
\hline & Epizeuxis & $\begin{array}{l}28-32 \\
36-38 \\
42-47 \\
\end{array}$ & $\begin{array}{l}\text { Si menor } \\
\text { Si menor } \\
\text { Si menor }\end{array}$ & $\begin{array}{l}\mathrm{iii} \\
\mathrm{iii} \\
\mathrm{iii} \\
\end{array}$ \\
\hline & Interrogatio & $30-34$ & Si menor & $\mathrm{iii}$ \\
\hline & Abruptio & 49 & Ré maior & V \\
\hline & Pausa & 50 & Ré maior & V \\
\hline & Aposiopesis & 56 & Ré maior & V \\
\hline \multirow[t]{2}{*}{ Confirmatio } & Synaeresis & $\begin{array}{l}57-59 \\
61,63 \\
\end{array}$ & $\begin{array}{l}\text { Sol maior } \\
\text { Sol maior }\end{array}$ & $\begin{array}{l}1 \\
1 \\
\end{array}$ \\
\hline & Epizeuxis & $64-65$ & Sol maior & 1 \\
\hline \multirow{2}{*}{ Peroratio } & Epizeuxis & $66-67$ & Sol maior & I \\
\hline & Synaeresis & $66-68$ & Sol maior & I \\
\hline
\end{tabular}

\section{Considerações finais}

Como salientado no decorrer deste artigo, nas estruturas de determinadas músicas nos fins do século XVII e começo do século 
XIX eram aplicados pelos mestres da composição diversos elementos retóricos a fim de atrair a atenção do ouvinte, através da persuasão. Certamente, para que esse procedimento pudesse ser exitoso, recursos retóricos como as figuras eram utilizados em conformidade às cadências, a harmonia, repetições e materiais motívicos, auxiliando dessa maneira o autor a distribuir ordenadamente o enunciado musical.

Cônscio da eficiência dessa finalidade, André da Silva Comes apropria-se desses mecanismos nessa peça, por exemplo, para destacar os afetos de júbilo e enaltecimento, manifestados na frase Laudate pueri Dominum (Louvai ó servos do Senhor), através da Epizeuxis, Palilogia e a Synaeresis. De igual maneira, para realçar as funções harmônicas da Tônica, Subdominante e Dominante, a entoação de duas notas em uma sílaba no solo da soprano, nos compassos 5 a 8 e a valoração do deslocamento intervalar e das cadências usadas nos compassos 12 e 15, mediante a Synaeresis, assim como as repetições de maneira modificada das palavras gloria eius, efetuada pela Synonymia, nos compassos 21 e 23.

Não obstante, para enfatizar o questionamento da expressão Quis sicut Dominus Deus noster, qui in altis habitat, et humilia respicit in caelo et in terra? (Quem há como o Senhor nosso Deus, que está nas alturas, e abaixa os olhos sobre o céu e sobre a terra?), com a figura da Interrogatio, juntamente com a Epizeuxis e Synaeresis. Finalizando, coloca em evidência, entre os compassos 48 e 69, os afetos expressados pelo salmista de alegria, engrandecimento e louvor, por meio das figuras já citadas e por outras três figuras retóricas de interrupção e silêncio: Abruptio, Aposiopesis e Pausa, além da Palilogia.

Em síntese, nos exemplos aqui examinados há de se ressaltar que a observação desses elementos e figuras retóricas, bem como do texto litúrgico, das funções harmônicas e dos afetos, evidencia o cabedal e arcabouço de André da Silva Gomes na formulação e organização do discurso musical, além da viabilidade do uso da retórica como ferramenta de análise para o entendimento dos processos composicionais utilizados pelos compositores no Brasil colonial. 


\section{Referências}

ABBACNANO, Nicola. Dicionário de filosofia. Tradução de Alfredo Bosi. 5. ed. rev. e ampl. São Paulo: Martins Fontes, 2007.

ALMEIDA, João Ferreira de. Biblia de Estudo de Genebra. São Paulo: Cultura Cristã; Sociedade Bíblica do Brasil, 1999.

BARTEL, Dietrich. Musica Poetica: musical-rhetorical figures in German Baroque Music. Lincoln: University of Nebraska Press, 1997.

BUELOW, George. Rhetoric and Music. In: SADIE, Stanley; TYRRELL, John (Orgs.), The new grove dictionary of music and musicians. New York: Oxford University Press, 200 1. v. 21 , p. 260-275.

DUPRAT, Régis. Música na Sé de São Paulo colonial. São Paulo: Paulus, 1995.

(Org.). Música sacra paulista. Marilia: Editora Unimar, 1999.

DUPRAT, Régis et al. A Arte Explicada de Contraponto de André da Silva Comes. São Paulo: Arte \& Ciência, 1998.

CUIMARÃES, Elisa. Figuras de retórica e argumentação. In: MOSCA, Lineide do Lago Salvador (Org.). Retóricas de ontem e de hoje. 3. ed. São Paulo: Humanitas, 2004. p. 1 45- 160.

JOACHIM, Harold H. A study ot the Ethics of Spinoza: Ethica Ordine Ceometrico Demonstrata. Oxford: Clarendon Press, 1901.

LÓPEZ CANO, Rubén. Música y retórica en el Barroco. México: Gráfica da Universidade Nacional Autônoma do México, 2000. 2 v.

REBOUL, Olivier. Introdução a retórica. Tradução de Ivone Castilho Benedetti. 2. ed. São Paulo: Martins Fontes, 2004.

SOARES, Eliel Almeida; NOVAES, Ronaldo; MACHADO NETO, Diósnio. Figuras retóricas no Ofertório da Missa de Quarta-feira de Cinzas de André da Silva Comes. Música Hodie, Goiânia, v. 12, n. 2, p. 71-86, 
jul./dez. 2012a. Disponivel em: <https://www.revistas.ufg.br/musica/article/ view/22631/13490>. Acesso em: 17 jul. 2017.

Retórica na música colonial brasileira: o uso da anaphora em André da Silva Comes. In: ENCONTRO DE MUSICOLOCIA DE RIBEIRÃO PRETO, 4., 20 12, Ribeirão Preto. Anais... Ribeirão Preto: Laboratório de Teoria e Análise Musical, 20 12b. p. 301-306.

SOARES, Eliel Almeida; MACHADO NETO, Diósnio. A Aposiopesis em André da Silva Gomes. In: SIMPÓSIO INTERNACIONAL DE MÚSICA NA AMAZÔNIA, Porto Velho, 2015. Anais... Boa Vista: Editora da UFRR, 2015. p. 337-348. Disponivel em: <https://drive.google.com/file/ d/OB76yJiCrjVAnS I p5ZnVrcGhaWfJU/view>. Acesso em: 21 jun. 2017.

O uso de elementos retóricos no Cloria da Missa Abreviada em Ré de Manoel Dias de Oliveira. In: SIMPÓSIO INTERNACIONAL DE MÚSICA IBERO-AMERICANA, 4. 2016, Belo Horizonte. Anais... Belo Horizonte: Escola de Música UFMG, 2016. p. 649-669.

\section{Sobre o autor}

Eliel Almeida Soares é graduado em Música, mestre e doutor em Musicologia pelo Programa de Pós-Graduação em Música da Escola de Comunicações e Artes da Universidade de São Paulo (ECA USP). Desenvolveu, por intermédio do Laboratório de Musicologia do Departamento de Música da Faculdade de Filosofia, Ciências e Letras de Ribeirão Preto da Universidade de São Paulo (LAMUS/DM/ FFCLRP/USP) e apoiado financeiramente com a bolsa de doutorado da Fundação de Amparo à Pesquisa do Estado de São Paulo (FAPESPProcesso n²0 13/23600-3), pesquisas sobre as estruturas discursivas na música colonial brasileira. Também possui diversos trabalhos publicados sobre retórica musical.

Recebido em 29/09/2017

Aprovado em 02/04/20 18 